\title{
Study the hydro-isomerization of light paraffin over bifunctional catalysts at elevated pressures
}

\author{
- Dao Thi Kim Thoa
}

- Luu Cam Loc

Ho Chi Minh City University of Technology, VNU-HCM

(Manuscript Received on October 13th, 2015, Manuscript Revised January 15th, 2016)

\begin{abstract}
Noble metal based catalysts being 0.8 wt. \%Pd and 0.35 wt. \%Pt supported on HZSM-5 zeolite were subjected to the investigation. Physico-chemical characteristics of catalysts were determined by the methods of nitrogen physi-sorption, SEM, XRD, TEM, $\mathrm{NH}_{3}-\mathrm{TPD}$, $T P R$, and Hydrogen Pulse Chemi-sorption (HPC). Activity of catalysts in the isomerization of $n-C_{6}$ and $n-C_{5}+n-C_{6}$ mixture was studied in a micro-flow reactor in the temperature range of $225-325^{\circ} \mathrm{C}$ at pressure of $0.1 \mathrm{MPa}$ and 0.7 $\mathrm{MPa}$; the molar ratio $\mathrm{H}_{2} /$ hydrocarbon: 5.92, concentration of $n-C_{5}$ or $n-C_{6}: 4.6$ mol. \%, GHSV $2698 \mathrm{~h}^{-1}$. The stability of catalysts was also

determined. The obtained catalysts expressed high acid density, good reducing property, and high metal dispersion with the cluster size in the range of nanometer. They were an excellent contact for isomerization of n-hexane or $n-C_{5}+$ $n$ - $C_{6}$ mixture with high conversion, selectivity, and yield. At optimal temperature, n-paraffin conversions were as high as $57-63 \%$ and selectivity was $90 \%$. Pressure had the positive effect to the catalyst conversion, selectivity, and stability. At 0.7 MPa, both catalysts produced 6669 RON liquid product containing friendly environmental iso-paraffins which is superior blending stock for green gasoline.
\end{abstract}

Key words: isomerization, light paraffin, Pd/HZSM-5, Pt/HZSM-5, pressure.

\section{INTRODUCTION}

The production of gasoline for automobiles has been becoming challenged in the aspect of environmental concerns. Being toxic tetraethyl lead, MTBE, benzene, and its derivatives are banded or gradually eliminated from the gasoline pool. In order to meet the strict gasoline specifications refineries have been forced to find out new processes and new catalysts to produce good blending stock for green gasoline.
Isomerate is rising as one of the excellent replacements for the required characteristics.

The skeletal hydro-isomerization of npentane $+n$-hexane mixture is an essential process to produce iso-pentane and iso-hexane for low aromatics gasoline. Bi-functional catalysts consisting of noble metals supported on micro-porous materials have been widely used

\section{Trang52}


for this reaction. Among the available supports, HZSM-5 showed to be superior [1]. However, it has been found that isomerization over bifunctional catalyst is influenced by the $\mathrm{H}_{2}$ spillover phenomenon [1]. The $\mathrm{H}_{2}$ migrating or spilling over from the noble metal sites onto the acidic support is responsible for the promoting effect of $\mathrm{H}_{2}$. However, this effect has been observed on limited numbers of catalysts. Therefore, finding out new catalyst with superior $\mathrm{H}_{2}$ spillover effect is evaluable for isomerization reaction. Metals like $\mathrm{Pd}$ and $\mathrm{Pt}$ have been found to be good active components for hydrogendehydrogenation functions as well the $\mathrm{H}_{2}$ spillover effect. The easy dissociation of hydrogen on their surfaces is responsible for those abilities. This work dealt with $\mathrm{Pd}$ and $\mathrm{Pt}$ catalysts supported on HZSM-5 for hydroisomerization of the mixture of n-pentane and nhexane. Several experiments had been conducted in order to find out the active catalysts.

Most of the studies on isomerization are carried out at pressures higher than atmospheric [2], [3] in order to be correlated with the industrial operation $\left(20-30 \mathrm{~kg} \mathrm{~cm}^{-2}\right)$ [4]. Neither a systematic study nor the selection of this parameter can be found in the literature although there are papers indicated that hydrogen is necessary for the isomerization reaction [5]. Allain [2] proposed the reaction order with respect to hydrogen is -0.7 and that can be explained by a kinetic bi-functional monomolecular model while Iglesia et al. [6] reported n-heptane isomerization rate showed positive hydrogen kinetic order. This study was conducted in order to study the actual effect of pressure to the catalyst activity and stability.

From those points of view two zeolite supported catalysts based on $\mathrm{Pt}$ and $\mathrm{Pd}$ were subjected to the investigation for the isomerization of n-pentane and n-hexane mixture at elevated pressures.

\section{EXPERIMENT}

$\left(\mathrm{NH}_{4}\right) \mathrm{ZSM}-5$ (Zeolyst International (USA)) was calcined at $500{ }^{\circ} \mathrm{C}$ for $3 \mathrm{~h}$ to obtain HZSM5. The metals were loaded to the carrier by impregnation method at the concentration of 0.8 wt. \% for Pd and 0.35 wt. \% for Pt according to the result of our previous works [7], [8]. Catalysts were assigned as follows: Pd/HZSM-5 means 0.8 wt.\% Pd on HZSM-5; Pt/HZSM-5 means 0.35 wt.\% Pt on HZSM-5.

Physico-chemical properties of the catalysts were characterized by methods of BET- $\mathrm{N}_{2}, \mathrm{SEM}$, TEM, XRD, TPR, $\mathrm{H}_{2}$ pulse chemi-sorption (HPC), and TPD. Activity of the studied catalysts was tested in a micro-flow reactor at the temperature range of $225 \div 325{ }^{\circ} \mathrm{C}$; mol ratio of $\mathrm{H}_{2}$ /hydrocarbons was 5.92; concentration of $\mathrm{n}-\mathrm{C}_{5}$ or $\mathrm{n}^{-\mathrm{C}_{6}}$ was $4.6 \mathrm{~mol} . \%$; GHSV $2381 \mathrm{~h}^{-1}$. The mixture of reaction products was analyzed on the GC Agilent Technologies 6890 Plus with a FID detector, and DB 624 column with $30 \mathrm{~m}$ of length and $0.32 \mathrm{~mm}$ of outer diameter.

\section{RESULTS}

SEM image of Pd/HZSM-5 catalyst presented rectangular cubic crystallites of zeolites with dimensions $90-263 \mathrm{~nm}$ for catalysts Pd/HZSM-5. Values of HZSM-5 crystallite size $\left(\mathrm{d}_{\mathrm{zeol}}\right)$ and zeolite particle dimension (d) varied in the ranges of 29.6 - 31.5 $\mathrm{nm}$ and 37.7 - $44.7 \mathrm{~nm}$, respectively (Tab. 1). Loading metal onto HZSM-5 more or less reduced the specific area of zeolite may be because of the pore blockage of the support by added metal species [9]. 
Catalyst Pt/HZSM-5 expressed higher metal dispersity and smaller metal crystallite size in comparison with Pd/HZSM-5. Table 1 showed that Pt has the dispersity of $76.99 \%$ and crystallite size of $1.5 \mathrm{~nm}$ while those of Pd are $23.3 \%$ and $5.0 \mathrm{~nm}$. Pd cluster size $\left(\mathrm{d}_{\mathrm{Pd}}\right)$ calculated by HPC and measured by TEM are relatively closed; on Pd/HZSM-5, $\mathrm{d}_{\mathrm{Pd}}$ is $5 \mathrm{~nm}$ by HPC and $7.36 \mathrm{~nm}$ by TEM (Fig. 1). Occhiuzzi found that on catalysts 0.88 wt. $\% \mathrm{Pd} / \mathrm{ZrO}_{2}-\mathrm{WO}_{3}$ the values $29.3 \mathrm{~nm}$ for quantity $\mathrm{d}_{\mathrm{Pd}}$ and $3.8 \%$ for Pd dispersity $\left(\gamma_{\mathrm{Pd}}\right)$, were observed [10]. Another work on 2.0 wt.\%Pd/HZSM-5 by Thomson specified the Pd crystallite size in the range of $12.5 \mathrm{~nm}$ with metal dispersion of $9.4 \%$ [11]. The differences between metal dispersion in our work and those in the others happened because the fact that, surface area of our catalyst $\left(298 \mathrm{~m}^{2} / \mathrm{g}\right)$ is much higher than that of $\mathrm{ZrO}_{2}-\mathrm{WO}_{3}\left(36 \mathrm{~m}^{2} / \mathrm{g}\right)$ and the metal content of our catalyst ( $0.8 \mathrm{wt} . \%)$ is lower than that in catalyst in Thomson's study (2.0 wt.\%). Relatively small metal crystallite sizes in this work are good for isomerization reaction [12].

EDS image of Pd/HZSM-5 (not shown) shows that $\mathrm{Pd}$ is distributed on catalyst surface fairly evenly and the value of $\mathrm{Si} / \mathrm{Al}$ on the surface is fairly high about 18 .

XRD patterns of catalysts were presented in Fig. 2. The peaks in the range of $2 \Theta=7-10^{\circ}$ and $22-25^{\circ}$ were identified as peak reflections of HZSM-5 zeolite [1]. The impregnation of Pd or Pt onto HZSM-5 did not change the peak position but slightly increased the intensity of the peaks and the crystallinity of HZSM-5 due to the elimination of distorted aluminum sites [1]. These results also indicated that Pd or Pt may interact with defect sites stabilizing the crystalline structure of HZSM-5 and making framework structure to be more ordered. The absence of characteristic peaks of Pd and Pt may be due to very small amounts of those species.

The negative peak at $75{ }^{\circ} \mathrm{C}$ in TPR diagram of $\mathrm{Pd} / \mathrm{HZSM}-5$ catalyst (Fig. 3, line 1) characterized the decomposition of palladium hydride formed through $\mathrm{H}$-diffusion within the Pd crystallites [13]. While Pt supported on HZSM- 5 is characterized by 2 reduction peaks at $202{ }^{\circ} \mathrm{C}$ and $402{ }^{\circ} \mathrm{C}$ (Fig. 3, line 2). Maora H. Jorda o also showed two reduction peaks at 270 ${ }^{\circ} \mathrm{C}$ and $400{ }^{\circ} \mathrm{C}$ for 1.0 wt. \% Pt/HUSY calcined at $500{ }^{\circ} \mathrm{C}$ [14]. Those peaks characterized the reduction of $\mathrm{Pt}^{4+}$ to $\mathrm{Pt}^{2+}$ and $\mathrm{Pt}^{2+}$ to $\mathrm{Pt}^{\circ}$.

Loading metal onto HZSM-5 resulted in the depression of acidity (Tab.1). This result was also announced by Ho Si Thoang [12] and Villegas [15]. This may be because of the replacement of proton $\mathrm{H}^{+}$of silanol group of HZSM-5 by the metal [16], [17]. Pd/HZSM-5 possesses relatively higher total acidity and acid strength compared to Pt/HZSM-5.

In the reaction of pure feed (Tab. 2) or mixed feed (Tab. 3) the activity of Pd/HZSM-5 and Pt/HZSM-5 are comparable but the lifetime of Pd/HZSM-5 is a little shorter than Pt/HZSM5. This may come from the fact that the higher acidity of Pd/HZSM-5 leading to the stronger cracking reaction and the shorter lifetime of Pd/HZSM-5 compared to Pt/HZSM-5.

\section{Trang54}




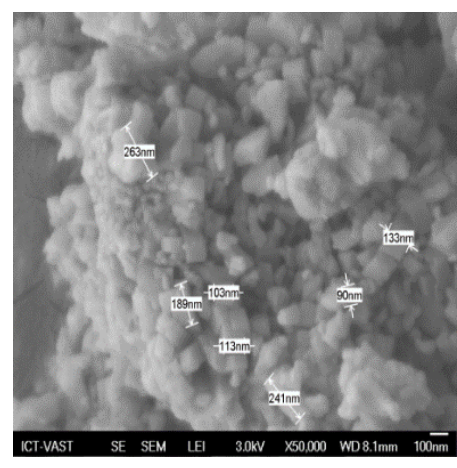

(a) SEM of Pd/HZSM-5

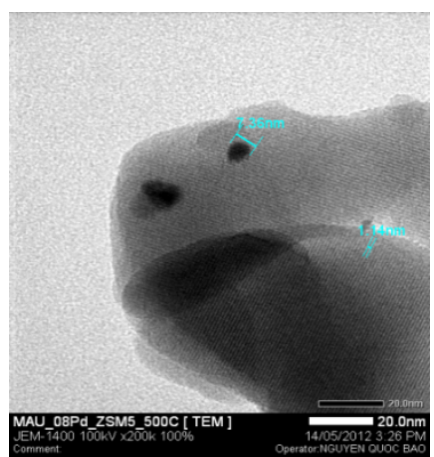

(b) TEM of Pd/HZSM-5

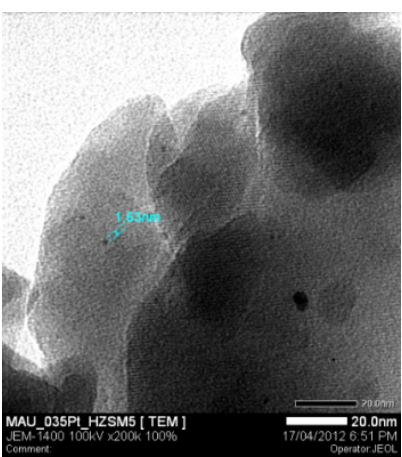

(c) TEM of Pt/HZSM-5

Figure 1. SEM and TEM images of catalysts

Table 1. Surface area $\left(\mathrm{S}_{\mathrm{BET}}\right)$; HZSM-5 crystallite size at $7.9^{\circ}\left(\mathrm{d}_{\mathrm{zeol}}\right)$; zeolite particle dimension by Scherrer equation $(d)$; Pd clusters size by TEM ( $\left.\mathrm{d}_{\mathrm{TEM}}\right)$, Pd clusters size by HPC $\left(\mathrm{d}_{\mathrm{Pd}}\right)$, Pd dispersity by $\mathrm{HPC}\left(\gamma_{\mathrm{Pd}}\right)$; and acidity by $\mathrm{NH}_{3} \mathrm{TPD}$

\begin{tabular}{|c|c|c|c|c|c|c|c|c|c|c|}
\hline \multirow[t]{2}{*}{ Catalysts } & \multirow{2}{*}{$\begin{array}{l}\mathrm{S}_{\mathrm{BET}} \\
\mathbf{m}^{2} / \mathrm{g}\end{array}$} & \multirow{2}{*}{$\begin{array}{c}\mathbf{d}_{\text {xeol }} \\
\mathbf{n m}\end{array}$} & \multirow{2}{*}{$\begin{array}{r}\mathbf{d} \\
\mathbf{n m}\end{array}$} & \multirow{2}{*}{$\begin{array}{c}\mathbf{d}_{\text {TEM }} \\
\mathbf{n m}\end{array}$} & \multirow{2}{*}{$\begin{array}{l}\mathbf{d}_{\mathbf{R d}} \\
\mathbf{n m}\end{array}$} & \multirow{2}{*}{$\begin{array}{l}\gamma_{R d} \\
\%\end{array}$} & \multicolumn{4}{|c|}{$\begin{array}{c}\text { Acidity } \\
\text { (mmol } \mathrm{NH}_{3} / 100 \text { g catalyst) }\end{array}$} \\
\hline & & & & & & & Weak & Medium & Strong & Total \\
\hline \multirow{2}{*}{ HZSM-5 } & \multirow{2}{*}{353} & \multirow{2}{*}{29.6} & \multirow{2}{*}{37.7} & \multirow{2}{*}{-} & \multirow{2}{*}{ - } & \multirow{2}{*}{-} & $206^{\circ} \mathrm{C}$ & - & $435^{\circ} \mathrm{C}$ & - \\
\hline & & & & & & & 80.96 & - & 60.69 & 141.65 \\
\hline \multirow{2}{*}{ Pd/HZSM-5 } & \multirow{2}{*}{298.0} & \multirow{2}{*}{31.5} & \multirow{2}{*}{44.7} & \multirow{2}{*}{7.36} & \multirow{2}{*}{5.0} & \multirow{2}{*}{23.30} & $206^{\circ} \mathrm{C}$ & $273^{\circ} \mathrm{C}$ & $462^{\circ} \mathrm{C}$ & - \\
\hline & & & & & & & 77.62 & 10.05 & 47.06 & 134.73 \\
\hline \multirow{2}{*}{ Pt/HZSM-5 } & \multirow{2}{*}{305.0} & \multirow{2}{*}{30.5} & \multirow{2}{*}{43.7} & \multirow{2}{*}{1.63} & \multirow{2}{*}{1.5} & \multirow{2}{*}{76.99} & $210^{\circ} \mathrm{C}$ & - & $414^{\circ} \mathrm{C}$ & - \\
\hline & & & & & & & 58.44 & - & 52.53 & 110.96 \\
\hline
\end{tabular}

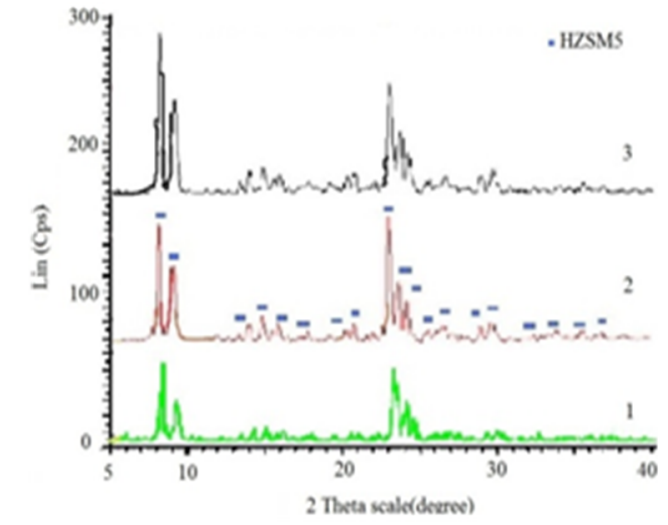

Figure 2. XRD pattern of catalysts

1) HZSM-5, 2) Pd/HZSM-5, 3) Pt/HZSM-5

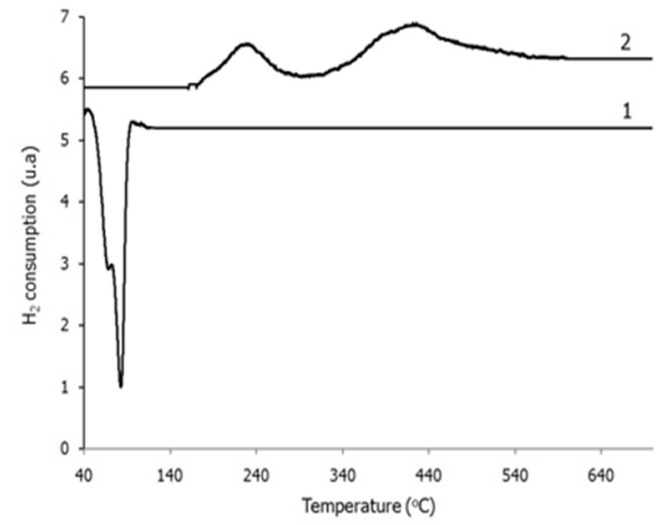

Figure 3. TPR diagram of catalysts

1) Pd/HZSM-5 and 2) Pt/HZSM-5 
The higher selectivity in the reaction of mixture compared to pure $\mathrm{C}_{6}$ one leading to the catalyst stability is much improved. The lifetime of Pd/HZSM-5 and Pt/HZSM-5 catalysts increased from $1 \mathrm{~h}$ and $4 \mathrm{~h}$ in case of the reaction of pure $\mathrm{C}_{6}$ to $7 \mathrm{~h}$ and $>30 \mathrm{~h}$ in case of a mixture, respectively. This fact can be explained by the lower concentration of $\mathrm{C}_{6}$ in feed [18] and the apparent energies of activation of cracking decreased with increasing chain length of the hydrocarbon [19].

Increasing pressure of the reaction from 0.1 $\mathrm{MPa}$ up to $0.7 \mathrm{MPa}$ helped to increase both catalyst conversion, selectivity, and, as a result, is the lifetime of catalyst (Tab.2 and Tab.3). The lifetime of Pd/HZSM-5 catalyst increased from 1 $\mathrm{h}$ (pure feed) and $7 \mathrm{~h}$ (mixed feed) to over $30 \mathrm{~h}$ when the pressure was brought up from $0.1 \mathrm{MPa}$ to $0.7 \mathrm{MPa}$. And those of Pt/HZSM-5 catalyst increased from $4 \mathrm{~h}$ (pure feed) to over $30 \mathrm{~h}$. impact to the catalyst conversion, selectivity, and stability. Iglesia and co-workers [6] found that isomerization rate has positive hydrogen kinetic order. They proposed that the reaction takes place via hydride transfer step which terminates the isomerized carbocation by hydride transferred from the neutral species.

They called those by the bi-functional bimolecular mechanism which sounds in contrast with the conventional mono-molecule mechanism. By proposing this kind of mechanism they also specified the rate-limiting step is the desorption of the intermediate. The same observation was made by Manoli and coworkers [20]. They found the maximal activity of $\mathrm{Pt} / \mathrm{SZ}$ in $\mathrm{n}$-hexane isomerization with increasing hydrogen partial pressure. At high hydrogen partial pressure, hydride ions are provided for rate-limiting desorption step leading to the improvement of catalyst activity.

It seems that high pressure has a good

Table 2. Comparison of the activity of Pd/HZSM-5 and Pt/HZSM- 5 catalysts in n-hexane isomerization at $0.1 \mathrm{MPa}$ and $0.7 \mathrm{MPa}$ (concentration of $\mathrm{C}_{6}: 9.2 \mathrm{~mol}$. \%)

\begin{tabular}{|c|c|c|c|c|c|c|c|}
\hline Catalysts & $\begin{array}{c}\text { Pressure } \\
\text { JPPa }\end{array}$ & $\begin{array}{c}\text { Topt } \\
{ }^{\circ} \mathrm{C}\end{array}$ & $\begin{array}{c}\text { X } \\
\%\end{array}$ & $\begin{array}{c}\text { Siso } \\
\%\end{array}$ & $\begin{array}{c}\text { Y } \\
\%\end{array}$ & RON & $\begin{array}{c}\boldsymbol{\tau} \\
\text { h }\end{array}$ \\
\hline \multirow{2}{*}{ Pd HZSM-5 } & 0.1 & 250 & 57 & 87 & 50 & 50 & 1 \\
& 0.7 & 250 & 79 & 98 & 77 & 66 & $>30$ \\
\hline \multirow{2}{*}{ Pt HZSM-5 } & 0.1 & 250 & 59 & 85 & 50 & 47 & 4 \\
& 0.7 & 275 & 76 & 99 & 75 & 63 & $>30$ \\
\hline
\end{tabular}

Table 3. Comparation of the activity of Pd/HZSM-5 and Pt/HZSM- 5 catalysts in isomerization of mixture* at $0.1 \mathrm{MPa}$ and $0.7 \mathrm{MPa}$ (concentration of n-C5 = n-C6 = $4.6 \mathrm{~mol} . \%$ )

\begin{tabular}{|c|c|c|c|c|c|c|c|}
\hline Catalysts & $\begin{array}{c}\text { P } \\
\mathbf{M P a}\end{array}$ & $\begin{array}{c}\text { T } \\
{ }^{\circ} \mathrm{C}\end{array}$ & $\begin{array}{c}\mathbf{X} \\
\%\end{array}$ & $\begin{array}{c}\text { Siso } \\
\%\end{array}$ & $\begin{array}{c}\text { Y } \\
\%\end{array}$ & RON & $\begin{array}{c}\tau \\
\text { h }\end{array}$ \\
\hline \multirow{2}{*}{ Pd/HZSM-5 } & 0.1 & 250 & 57 & 89 & 51 & 63 & 7 \\
& 0.7 & 250 & 69 & 99 & 68 & 68 & $>30$ \\
\hline \multirow{2}{*}{ Pt HZSM-5 } & 0.1 & 250 & 63 & 95 & 60 & 69 & $>30$ \\
& 0.7 & 300 & 77 & 73 & 56 & 69 & $>30$ \\
\hline
\end{tabular}

\section{Trang56}


At low hydrogen partial pressure, there are less hydride transfer phenomena leading to the longer lifetime of surface intermediate. In this situation, cracking and oligomerization will dominate at short residence time; polymerization and coke formation will dominate at long residence time leading to the depression of catalyst lifetime.

\section{CONCLUSIONS}

Catalyst Pt/HZSM-5 expressed higher metal dispersity, smaller metal crystallite size, and lower acidity in comparison to Pd/HZSM-5. The advantage of Pt based catalyst over Pd based catalyst is that its lifetime is little higher than that of Pd catalyst at atmospheric pressure.
The presence of n-pentane in the mixture elevated reaction conversion, reaction selectivity, and catalyst lifetime.

Pressure had a positive effect to the reaction conversion, reaction selectivity, and catalyst lifetime. At $0.7 \mathrm{MPa}, \mathrm{Pd}$ and $\mathrm{Pt}$ supported catalysts produced 66-69 RON liquid product containing friendly environmental iso-paraffins which are superior blending stock for green gasoline.

Acknowledgments: This research is funded by the Vietnam National University - Ho Chi Minh City (VNU-HCM) under grant number $C$ 2014-20-15.

\section{Nghiên cứu phản ứng hydro-isomer hóa n- paraffins nhẹ trên xúc tác lưỡng chức năng ở áp suất khác nhau}

- Đào Thị Kim Thoa

- Lưu Cẩm Lộc

Trường Đại học Bách khoa, ĐHQG-HCM

\section{TÓM TĂT}

Xúc tác 0,8 \%kl.Pd/HZSM-5 và 0,35\%kl.Pt/HZSM-5 được tổng hợp bằng phwơng pháp tẩm uoót. Các tính chất lý-hóa của xúc tác được xác định bằng các phuoong pháp: hấp phu vật lý N2, SEM, XRD, TEM, NH3-TPD, $T P R$, và chuẩn độ xung (HPC). Hoạt tính của xúc tác cho phản úng isomer hóa hôn hơp n-pentane và n-hexane được nghiên cứu trên thiết bi phản úng dòng vi lương trong khoảng nhiệt độ tù 225 -
325 oC ở 0,1 và 0,7 MPa; tỷ lệ mol H2/ hydrocarbon là 5,92 với tỷ lệ n-pentane: $n$ hexane là 1: 1 tuoong úng với nồng độ mối chất là 4,6\% mol. Xúc tác có độ acid cao, dễ khủ, và độ phân tán kim loại cao với kích thước hạt kim loại vào khoảng $n m$. Xúc tác có hoạt tính cao cho phản ứng isomer hóa n-hexane và hốn hợp $n$ pentane $+n$-hexane trong điều kiện khảo sát. Ở điều kiện áp suất 0,7 MPa hoạt tính và độ bền 
của xúc tác được cải thiện đáng kể so với điều kiện 0,1 MPa. Cả hai xúc tác đều có hoạt tính ổn định và cho sản phẩm có chỉ số octane trong khoảng 66-69 và chất lương cao để pha xăng thân thiện với môi truờng.

Tù khóa: isomer hóa, paraffin nhe, Pd/HZSM-5, Pt/HZSM-5, áp suát.

\section{REFERENCES}

[1]. Setiabudi HD, Jalil AA, Triwahyono S, Kamarudin NHN, and Mukti RR. IR study of iridium bonded to perturbed silanol groups of Pt-HZSM5 for n-pentane isomerization, Applied Catalysis A: General 2012; 190-199.

[2]. Allain JF, Magnoux P, Schulz Ph, Guisnet M. Hydroisomerization of n-hexane over platinum mazzite and platinum mordenite catalysts kinetics and mechanism, Applied Catalysis A: General 1997; 221-235.

[3]. Holló A, Hancsok J, Kalló D. Kinetics of hydroisomerization of $C_{5}-C_{7}$ alkanes and their mixtures over platinum containing mordenite, Applied Catalysis A: General 2002; 93-102.

[4]. Ono Y. A survey of the mechanism in catalytic isomerization of alkanes, Catalysis Today 2003; 3-16.

[5]. Ebitani K, Konishi J, and Hattori H. Skeletal isomerization of hydrocarbons over zirconium oxide promoted by platinum and sulfate ion, Journal of Catalysis 1991; 257 267.

[6]. Iglesia E, Soled SL, and Kramer GM. Isomerization of Alkanes on Sulfated Zirconia: Promotion by Pt and by adamantyl hydride transfer species, Journal of Catalysis 1993; 238-253.

[7]. Luu Cam Loc, Dao Thi Kim Thoa, Pham Nhu Thuan, Bui Thanh Huong, Ho Si Thoang. Effect of treatment temperature of $\mathrm{NH}_{4} \mathrm{ZSM}$ 5 and $\mathrm{HZSM}-5+-\mathrm{Al}_{2} \mathrm{O}_{3}$ on physico-chemical properties and activity of $P d$ in $n$-hexane isomerization, Journal of Chemistry 2012; 324-328.

[8]. Luu Cam Loc, Dao Thi Kim Thoa, Bui Vinh Tuong, Nguyen Tri, Giang Thanh Hung. Investigation into $n$-hexane isomerization over Pt/HZSM-5 catalysts, Journal of Chemistry 2012; 320-323.

[9]. Eswaramoorthi I and Lingappan N. Activity, selectivity and stability of $\mathrm{Ni}-\mathrm{Pt}$ loaded zeolite- and mordenite catalysts for hydroisomerisation of $n$-heptane, Applied Catalysis A: General 2003; 469-486.

[10].Occhiuzzi M, Cordischi D, Rossi SD, Ferraris G, Gazzoli D, Valigi M. $P d$ promoted $\quad \mathrm{WOx} / \mathrm{ZrO}_{2} \quad$ catalysts: Characterization and catalytic activity for $n$ butane isomerization, Applied Catalysis A: General 2008; p. 29-35.

[11].Thomson RT and Wolf EE. Hydrocarbon synthesis over palladium/ZSM-5 bifunctional catalysts, Applied Catalysis 1988; 65-80.

[12].Ho Si Thoang, Luu Cam Loc. Transformation of hydrocarbon and CO over metal and metal oxide catalysts, Hanoi, Natural science and technology publisher (2007) (Vietnamese).

[13].Chang TC, Chen JJ, and Yeh CT. Temperature-programmed reduction and temperature-resolved sorption studies of strong metal-support interaction in supported palladium catalysts, Journal of Catalysis $1985 ; 51-57$.

\section{Trang58}


[14].Jordão MH, Simões V, and Cardoso D. Zeolite supported Pt-Ni catalysts in n-hexane isomerization, Applied Catalysis A: General 2007; 1-6.

[15]. Villegas JI, Kumar N, Heikkila T, Lehto VP, Salmi T, Murzin DY. Isomerization of $n$ butane to isobutane over Pt-modified Beta and ZSM-5 zeolite catalysts: Catalyst deactivation and regeneration, Chemical Engineering Journal 2006; 83-89.

[16].Karthikeyan D, Lingappan N, Sivasankar B, Jabarathinam NJ. Activity and selectivity for hydroisomerisation of $n$-decane over $\mathrm{Ni}$ impregnated Pd/H-mordenite catalysts, Applied Catalysis A: General 2008; 18-27.

[17].Lingappan I and Lingappan N. Ni-Pt/H-Y zeolite catalysts for hydroisomerization of $n$ hexane and n-heptane, Catalysis Letters 2003; 133-142.
[18].Radhi MA, Al-Mutawalli FS, and AlSammarie EA. Isomerization of n-hexane and n-pentane mixture on Pt-alumina catalyst, Fuel Science and Technology International 1989; 143-163.

[19]. Narbeshuber TF, Vinek H, and Lercher JA. Monomolecular Conversion of Light Alkanes over H-ZSM-5, Journal of Catalysis 1995; 388-395.

[20]. Manoli JM, Potvin C, Muhler M, Wild U, Resofszki G, Buchholz T, and Paal Z. Evolution of the catalytic activity in Pt/sulfated zirconia catalysts: structure, composition, and catalytic properties of the catalyst precursor and the calcined catalyst, Journal of Catalysis 1998; 338-351. 